\title{
Varixvérzés
}

- Vitális Zsuzsanna dr.

Debreceni Egyetem AOK, Belgyógyászati Intézet, Gasztroenterológiai Tanszék, Debrecen

Correspondence: vitalis@med.unideb.hu

Májzsugoros beteg felső tápcsatornai vérzése esetén varixvérzést kell feltételezni, mivel jóval gyakoribb, mint az egyéb lokalizációból származó vérzések. Légútbiztosítás után az első lépés a keringés stabilizálása és a szükséges laboratóriumi vizsgálatok elvégzése, köztük a vércsoport meghatározása. Két brilizálása és a szúkseügèn laboratoriumi viźnát kell biztosítani, és el kell indítani az intravénás folyadékpótlást, amely során a restriktív branülön át vénát kell biztositani, és el kell indítani az intravénás folyadékpótlást, amely során a restriktív töltés elvét kell érvényesíteni. A beteget a súlyos alapbetegsége miatt lehetöleg intenzív osztályon kell elhelyezni. A felső tápcsatornai vérzés észlelésekor, még az endoszkópiát megelőzően el kell indítani az oktreotid- vagy terlipressinkezelést, illetve az antibiotikumprofilaxist. A keringésstabilizálást követően, de mindenképpen 12 órán belül meg kell hogy történjen a gasztroszkópia és a lokális vérzéscsillapítás. Varixvérzés esetén akkor is el kell végezni a ligációt (szkleroterápiát), cianoakrilát-kezelést, ha aktuálisan vérzés már nem észlelhető. Amennyiben a $\mathrm{Hgb} 70 \mathrm{~g} / \mathrm{l}$ alatti, amint a vér megérkezik, a transzfúziót el kell indítani, de az értékét $90 \mathrm{~g} / \mathrm{l}$ fölé lehetöleg ne emeljük! Az antibiotikumot legalább 5 napig, az intravénás vazopresszorokat minimum 3 napig kell alkalmazni.

KULCSSZAVAK: antibiotikumprofilaxis, vazopresszor-kezelés, restriktív volumenrendezés és transzfúzió, endoszkópos ellátás

\section{Variceal bleeding}

In case of an upper gastrointestinal bleeding in cirrhotic patients, variceal bleeding must be suspected as it is much more common than bleeding from other localizations. After airway securing, the first step is the restoring of hemodynamic stabilization and preforming necessary laboratory tests, including blood group determination. Two veins should be provided through two catheters and intravenous fluid replacement should be initiated promptly. A restrictive volume resuscitation and transfusion strategy is suggested. The patient requires intensive care due to severe underlying liver disease. Vasoactive treatment (octreotide or terlipressin) and antibiotic prophylaxis should be started before endoscopy when upper gastrointestinal bleeding is detected. (1) mission. Endoscopical treatment (ligation, sclerotherapy, cyannacrylate injection) should be performed even when bleeding is no longer detectable. If the hemoglabine the transfusion should be started, but do not increase the hemoglobin level above $90 \mathrm{~g} / \mathrm{l}$ ! The prophylactic antibiotic treatment is needed for at least 5 days and the intravenous vasopressor therapy for at least 3 days. KEYWORDS: antibiotic prophylaxis, vasopressor, restrictive volume restitution and transfusion strategy, endoscopic treatment

\section{Bevezetés}

A varixvérzés $(\mathrm{VV})$ a májzsugor második leggyakoribb dekompenzációs eseménye (az ascites után). A diagnosztika és a terápia jelentős javulása után a halálozás avult, de még ma is a betegek kb. 20\%-át elveszítjük.

\section{Cirrózis és portális hipertenzió}

A porta nyomása a varixrupturának és a vérzés súlyossáátalakulás és a gyulladás miatt aktiváódó és myofibrocyső gasztrointesztinális vérzése az esetek 70\%-ában VV

tává alakuló stellate sejtek összehúzódása miatt a máj érellenálása nö. A rezisztenciafokozódás 70\%-áért a mechanikus osszenyomás, 30\%-áért a funkcionális komponensek felelosek (2). A párhuzamosan növekvő nyírófeszültség aktiválja az endothelsejteket. A felszabaduló NO vazodilatációt okoz a szplanchnikus területen, amely a porta nyomását tovább növeli (3). A nyomás bizonyos szintje felett a belek pangása és egyéb tényezők miatt kórossá válik az intesztinális bakteriális transzlokáció, amelynek tovább vazodilatációs hatása van. A portális hipertenzió a májzsugor elörehaladásával folyamatosan emelkedik. Mérése hepatovenozus nyomásgradiens (HVPG) meghatározásá-
1. táblázat: A felső tápcsatornai vérzéssel érkező májzsugoros beteg állapotának értékelése

\begin{tabular}{|c|c|}
\hline Anémia & $\operatorname{Hgb}(g / l)$ \\
\hline Infekció & $\begin{array}{l}\text { CRP }(g / l), F V S(g / l), \text { PCT }(\mu \mathrm{g} / l) \text {, } \\
\text { sze. tenyésztések }\end{array}$ \\
\hline Keringés & $\begin{array}{l}\text { RR (Hgmm) } \\
\text { MAP (Hgmm) } \\
\text { Pulzus (/perc) }\end{array}$ \\
\hline Légzés & $\begin{array}{l}\text { Légzésszám (/perc) } \\
\mathrm{SO}_{2}\end{array}$ \\
\hline Vese & $\begin{array}{l}\text { Vizeletmennyiség (ml/24 óra) } \\
\text { Kreatinin ( } \mu \mathrm{mol} / \mathrm{l}) \\
\text { GFR }\end{array}$ \\
\hline Tudatműködés & $\begin{array}{l}\text { Időben való tájékozottság } \\
\text { Térben való tájékozottság } \\
\text { GCS-pontszám } \\
\text { HE (West Haven Grade) }\end{array}$ \\
\hline Májműködés & öBi ( $\mu \mathrm{mol} / /)$ \\
\hline Koaguláció & INR \\
\hline
\end{tabular}

val történik. A varixok kialakulása 10 Hgmm-es HVPG-né indul meg. Ezt tekintjük a klinikailag szignifkáns értéknek. 12 Hgmm felett várható VV (4).

\section{Diagnózis}

Ismert, vagy nagyon valószínüen cirrózisos beteg felezért minden májzsugoros betegben kialakuló felsô

\section{2. táblázat: A felső tápcsatornai vérzés súlyosságának értékelés}

Glasgow-Blatchford pontrendszer

\begin{tabular}{|lc|}
\hline Felvételkori laborparaméterek & Pont \\
\hline UREA $(\mathbf{m m o l} / \mathbf{l})$ & \\
\hline $6,5-<8,0$ & 2 \\
\hline $8,0-10,0$ & 3 \\
\hline $10,0-<25,0$ & 4 \\
\hline$>25,0$ & 6 \\
\hline
\end{tabular}

HGB (férfi, g/l)

tápcsatornai vérzést mindaddig VV-nek kell tartani, és ennek megfelelően kell kezelni, amíg egyéb ok nem gazolodik (5). A VV nagyon gyakran haematemesisse jelentkezik, de sok esetben a beteg beszámol arról hogy már napok óta fekete a széklete. A látványos vérès elött ugyanis a varixok vérezgethetnek. Az enyhe vérzés 40-50\%-ban megáll, és kb. 40\%-ban újraindul az első 5 napban (6). A beteg figyelmét a gondozás idején fel kell arra hivni, hogy ilyen esetben azonnal jelentkezzen. Barr a hirtelen kialakuló nagy vérzés esetén a laboratóriumilag detektálható anémia csak néhány óra múlva jelenik meg, az emlitett elöverezgetesek miatt ezek a betegek már kezdetben is lehetnek anémiásak. Nagy volumenủ vér hirtelen elvesztésekor a keringés instabil-

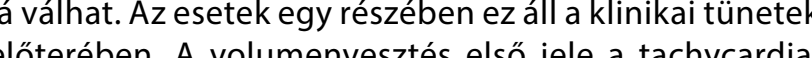
előterében. A volumenvesztés első jele a tachycardia, majd az ortostasis (a beteg gyakran a WC-be igyekezve kollabál), és végül a manifeszt hipotónia. Ilyenkor a rectalis vizsgálat kapcsán észlelt melaena segíti a diagnózist. A szapora szívmüködést komolyan kell venni, mer a kardialis rezerv kimerülése hirtelen bekövetkezhet, és a keringés néhány pillanat alatt összeomolhat. A beteg allapotának értékeléséhez szükséges vizsgálatokat az áblázatban részletezzük.

A vérzessforrás biztos megállapítása endoszkópiával törtéző, azonban nagyon fontos, hogy a vizsgálatot megelóután következst leghón gúlyośćt még az elso 12 orában javasolt (5). A verzés pontrendszer segítségévi lehet a Glasgo

A varok legtöbbször a nyelöcsőben láthatóak de az eseA varixok legtöbbször a nyelócsőben láthatóak, de az esedulnak. Gastrooesophagealis varixok estén a tágult vénák

$\begin{array}{ll}>120 & 1 \\ >100-<120 & 3 \\ <100 & 6\end{array}$

HGB (nő, g/l)

$$
>100-<120
$$

$<100$

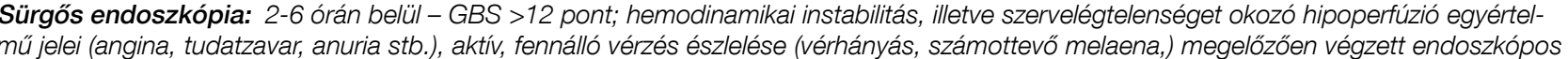

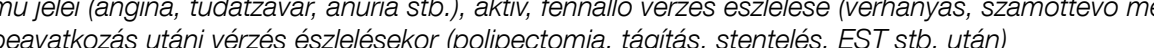
Korai elektivi endoszkópia: 6-12 órán belül - GBS 3-12 pont; hemoglobiin <80 g/l, illetve 24 órán belüli csökkenés >20 g/l, fus >12 g/ Elektiv endoszkópos vizsgálat: 12 órán túl - GBS: 1,2 pont (ez varivvérzés gyanúja esetén nem alkalmazandó)
Szisztolés vérnyomás (Hgmm)

100-109

$99-100$

Kiegészítő paraméterek

Pulzus $>100 / \mathrm{min}$

Melaena

Szinkópe

Májbetegség

Szívelégtelenség 
1. ábra: A varixvérzés diagnosztikájának és kezelésének algoritmusa

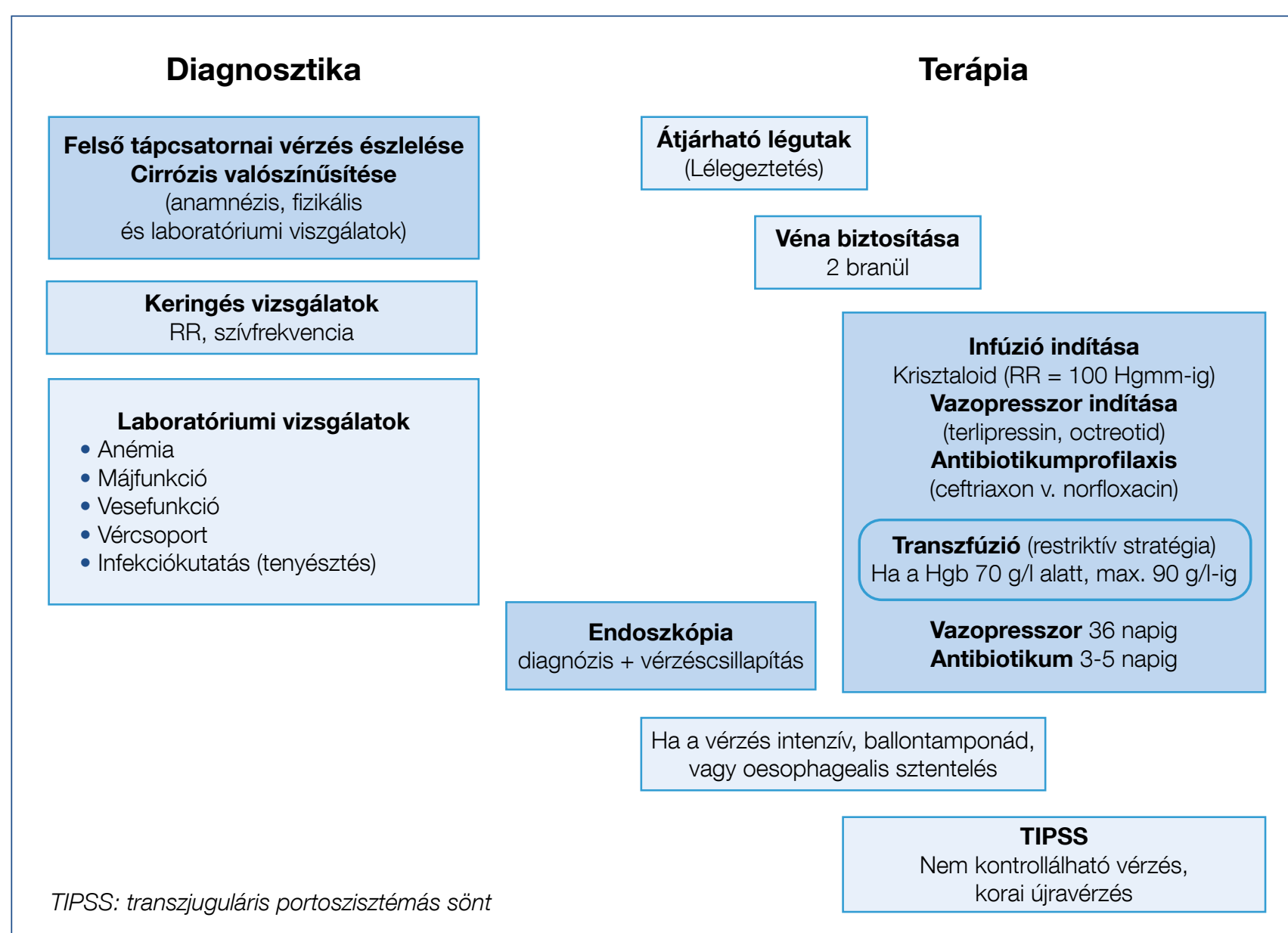

a nyelöcsőből a kardián túl a kisgörbületre (GOV1) vagy fundusba futnak (GOV2). Izoláltan is megjelenhetnek a fundusban (izolált gyomorvarix = IGV 1. típus), vagy a gyomor A VV magas szövődményrátával és mortalitással járó süregyéb területein (IGV 2. típus) (7). A fundusban lévő varixok gősségi állapotot jelent, amely intenzív ellátást igényel (5) ritkábban véreznek, de nehezebb a csillapításuk, mint az A kezelési stratégia felépítéséhez nagyon fontos ismern egyéb területeken látott visszértágulatoké. Mivel a későbbi- a VV várható lefolyását. Az első 5 napon belül a betegek ekben részletezett terápiás lépések miatt előfordul, hogy ak- halálát a kivérzés és az ehhez társuló keringés-összeomtuálisan vérzés nem észlelhető, emiatt fontos tisztázni, hogy lás okozza, vagyis a vérzés kontrolljának sikertelensége. mikor tekinthető a vérzés varix eredetúnek. Az első bavenói Az 5. nap után az első 6 hétben a szövődmények (pl. in ajánlás (8) alapján VV okozza a tüneteket, ha az endoszkópia fekciók, hipoxiás májkárosodás) vezethetnek a beteg haalkalmával varixokból származó aktív vérzés látható (lövellő lálához (10).

vagy folyamatosan szivárgó), ha a varixokon a közelmúlt- A kezelés első lépése a keringés stabilizálása. Aktív vérban lezajlott vérzés jelei láthatóak (fehér fibrincsomó vagy zésre utaló jelek és hemodinamikai instabilitás esetén nem lemosható, átfedő vérrög), vagy ha varixok láthatóak, amilyen gyorsan lehet, el kell kezdeni a volumenpótlást. a gyomorban vér van, és egyéb vérzésforrás nem azonosít- Ebböl a célból krisztaloid oldatot használunk (Isolyte-ot ható. Célszerú még ide sorolni az Ázsiai Májkutató Társaság Ringer-laktátot). A kolloidoldatok előnye VV esetén nem ajánlása (9) alapján azokat az eseteket, amikor ugyan vér bizonyítható (5). Helyes a beteg perifériás vénáiba két nincs a gyomorban, de a varixokon vörös jelek láthatóak, branült helyezni. A töltés ütemét a hiányzó vértérfogat és egyértelmúek a felső tápcsatornai vérzés jelei. A vérzés mennyiségéhez kell szabni, amihez a beteg vérnyomávarix eredetét azért fontos tisztázni, mivel a varixok en- sának és szívfrekvenciájának folyamatos követése, monidoszkópos ellátása ezekben az esetekben kötelező, akkor torizálása szükséges. Az induló dózis $20 \mathrm{ml} /$ testsúlykilois, amikor aktív vérzés már nem látszik, mivel az újravér- gramm. Alacsony vérnyomás esetén a bevitt folyadékkal zés megelőzésében a kombinált terápia (endoszkópos + a 100 Hgmm elérését kell megcélozni, e fölé nem szabad gyógyszeres) hatékonysága magasabb a monoterápiáénál emelni, a túltöltéstől tartózkodni kell (11). A vérpótlás (lásd később) (9).

Central European Journal of Gastroenterology and Hepatology

Volume 7, Issue 3 / October 2021

során is a restrikciós szabályokat kell betartani: vér adása csak akkor szükséges, ha a hemoglobin (Hgb) kisebb mint $70 \mathrm{~g} / \mathrm{l}$, és korrekciókor nem szabad $90 \mathrm{~g} / \mathrm{l}$ fölé emelni az értékét. Az érpálya túltöltése emeli a porta nyomását, és emiatt csökkenti a vérzés megállásának esélyét növeli az újravérzés kockázatát (5). Ezektől az értékektô akkor kell eltérni, ha a betegnek olyan társbetegsége van, ami a keringési alkalmazkodást csökkenti, vagy más módon a szervek perfúzióját rontja (pl. súlyos érszúkület). Ugyancsak figyelmeztető jel, ha a beteg laktátszintje alacsony $(<8 \mathrm{mmol} / /)$, mivel ez oxigénhiányt jelez, és ez esetben magasabb Hgb-érték relatíve gyors elérésére van szükség a hipoxiás károsodások megelőzéséhez (12) Alacsony oxigénszint esetén (<94-96\%) oxigénbelélegeztetés indokolt (11)

Ha a beteg encephalopathiás, proffúzan hány, az átjárható légutak biztositására, az aspiráció profilaxisára különôs figyelmet kell forditani, akár intubáció is szúkségess válhat (5). A beteg észlelése kapcsán erről is korán döntést kell hozni.

A VV kialakulását az infekciók fokozzák (a betegek kb. 20\%-ában a fertőzés a VV provokáló tényezője), illetve a $\checkmark$-t követôen nagyon gyakran (kb. a betegek $50 \%$-ában) alakul ki fertozés, spontán bakterialis peritonitis, pneumónia stb. Ez rontja a vérzés kontrollalhatóságát, novel az újravérzés kockázatát, es jelentossen rontja a 6 héten

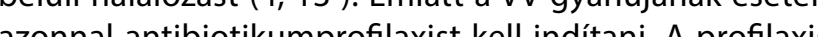
azonnal antibiotikumprofilaxist kell inditani. A profilaxis köteliső" Ha a beteg alkalmas a szájon át tö kzzeleź. Ha a beteg alla mas a szajon at tóténo gyógyszerelésre, napi $2 \times 400 \mathrm{mg}$ norfoxacin adása javasolt. jából tartós kinol a jából tartós kinolonproflaxist kapott, vagy 2.) az adott ellátohelyen gyakori a magas kinolonreziszzencia-arány,

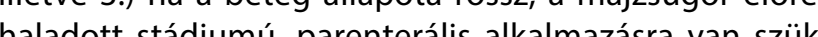
ség napi $1 \mathrm{~g}$ ceftriaxon iv. ad́sa indolt A vérzés miat ség, napi $\mathrm{g}$ ceftriaxon iv. adása ind 7 t. A verzés miat tel arra hogy Child Pugh A stádiumban az infekciós kockázat alacsony (14) megfelően táplált a vérzésen tú egyéb dekompenzációs jellel nem bíró betegek eséć a profilaxistól eltekinthetünk. (A diagnosztikus és téá ás lépések egymáshoz viszonyított időbeni elrendezés a mutatia a bra.)

3. táblázat: A varixvérzés során használt vazopresszorok adagolása

\section{ndukció}

Indukcio

Szomatosztatin $250 \mu g^{*}$

Oktreotid $\quad 50 \mu g^{*}$

Terlipressin Nincs

$250 \mu \mathrm{g} / \mathrm{óra}^{\star \star}$

25-50 $\mu \mathrm{g} / \mathrm{or}^{*}{ }^{\star *}$

$2 \mathrm{mg} / 4$ óra iv.

(50 kg testsúly alatt

$1 \mathrm{mg} / 4$ ora) 48 oran

$1 \mathrm{mg} / 4$ óra*

* bolusban; * * folyamatos infúzióban
Májzsugoros betegben a megnyúlt INR alapján nem következtethetünk arra, hogy a beteg vérzékeny. A globális haemostasis vizsgálatok (tromboelasztográfia [TEG] trom boelasztometria [ROTEM]) alapján a normálisnál hosszabb vérzési idók ellenére a haemostasis a legtöbb esetben a trombozisképzódés irányába tolódik el (15). Emiatt rutinszerúen sem friss fagyasztott plazma (FFP), sem faktorok adása az alvadási idők korrekciója céljából nem javasolt. Nem lehet velúk korrigalni a haemostasiseltérést, így nem javitják a vérzés kimenetelét, fokozzák azonban a trombózis kialakulásananak eselyêt (16). Raadásul az FFP jelentós volum ami nem tervezett hirtelen vérnyomás-emelkedes miatt a vêrzés ujraindulásához vezethet. Thrombocytakészztmeny adására sincs szükség, amíg a vérlemezkeszám $>50 \mathrm{~g} / \mathrm{l}(17)$

A verzéscsillapítás törtéhet gyógyszeresen, endoszkópos ellááassal, ballontamponáddal vagy transzjuguláris más sônt (TIPSS) behelyezé-

Gyógyszeres vérzéscsillapításra oktreotid (szomatosztatin-analóg) szomatosztatin vagy terlipressin (vazopreszszin-analóg) hasznáható. Hatásukra csokken a portaban (r. megáll (5). Az adagolást a 3. táblázat mutatja.

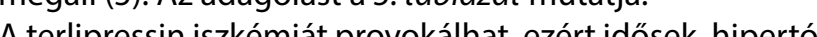
niások, kardiovaszkuláris betegségben szenvedok estó pontos követés indokolt. Szeptikus szonvedók esetén pos szas blokkolót ki kell hagyni (5).

Endoszopia elöt 20-120 perccel prokinetikum (eritromitgyomoürülést gyorsítva a látási viszonyok, mivel a guyanakor a túlélésre a kimenetelre nincsenek hatással (18) Az antibiotikum prokinetikumként való a (ás vannak.

Endoszkópos vérzéscsillapításra nyelőcsővarixok esetén alkalma a szkleroterápia és a varixligáció (endoscopic band ligation, EBL) is. Az utóbbinak kevesebb a szövödménye és nagyobb valószínúséggel állítható meg vele VV (19) ám jelentős vérzés esetén a kivitelezése nehezebb Tehet, mint a szkleroterápićé Ligácí́ során a varixokat gumigyürü vagy hurok segítségével leszorítjuk ami miatt megszünik bennük az áramlás, később a leszoritott rész elhal, lelöködik. Helyén kisebb-nagyobb fekély keletkezik, amely egyes esetekben ismételt vérzés forrása lehet. Van adat arra, hogy ligációt követően 9 napig alkalmazott protonpumpagátló csökkenti a fekélyek méretét és a belölük származó vérzés valószínüségét (20). Szkleroterápia során a varixokba és melléjük aethoxysklerolt injektálunk. Ez lokális ödémát, később hegesedést provokál, amely szintén a vérzó vénák elzáródásához vezet. Ha a szangvináció gyomorvarixból származik, EBL végzését, vagy a vérzó varix cianoakriláttal történoó beinjektálását javasolják (21). A két módszer egyformán hatékony, de cianoakrilát-kezelés után ritkább az újravérzés. Az EBL viszont technikailag egyszerübb (22). 
Ha nem sikerül a vérzést megállítani, a nyelőcsőbe helyezett ballon vízzel történő feltöltésével tamponálhatjuk a varixokat. Nyelőcsővarixok esetén SengstakenBlakemore-szonda, fundális varixvérzés esetén Lintonszonda használható. A pozicionálásuk gyakorlatot igényel. A nem megfelelően behelyezett ballon elzárhatja a légutakat. 4-6 óránként célszerü legalább átmenetileg felengedni, mivel a tartós nyomás a nyálkahártya keringésének akadályozása miatt annak elhalását okoz hatja (8). Ezek mellett a ballontamponád alternativájaként öntáguló nyelőcsősztent behelyezésére van lehe-
tőség (23).

A fenti beavatkozások a betegek 85\%-ában elegendőe a vérzés megállitásához, azonban $\mathrm{kb}$. 15\%-ukban sikertelen a vérzéskontroll, illetve korai ujraverzés alakul $k i$ Ez esetben akut transzjugularis intrahepatikus portoszisztèmás sônt (TIPSS) helyezhetó be. A sont csokkenti a porta nyomásá, azonban lehetnek szovódmenyei (lás

VV idején kerülni kell a nefrotoxikus gyógyszerek, min az aminoglikozidok vagy a nem szteroid gyulladáscsokkentok (NSADD) alkalmazását. Hasonlóan tartozzkodn ell a nagy volúná (> cón rérny a b́scsökkentő szer, a vaz). A hepatikus enegyeb vera charidok adhatók (19).

\section{A beteg elhelyezése}

A beteget, amennyiben lehetőség van rá, célszerú intenzív osztályon vagy állandó felügyeletet biztositó, gasztroenterológus által felügyelt vérzỏ szubintenzív oszzályon (szakmaspecifikus örzőben) elhelyezni. Nem egyszerüen a vérzés szövődményeivel kell számolnunk, hanem a súlyos alapbetegséggel (májzsugor) is, amely a kezdetben átszólag stabil betegben is hirtelen összeomlást okozhat Bárhol is helyezik el a beteget, a folyamatos szívfrekvencia és vérnyomás-monitorozás, a tudatállapot és a vesefunkció követése elengedhetetlen.

\section{A varixvérzés profilaxisa}

Primer és szekunder profilaxis során a porta nyomásának csökkentését célozzuk meg, vagy a vérzés szempontjábó magas kockázatúnak tortható vénatágulatok elzárásár törekszünk. A nem szelektív béta-blokkolók (NSBB) csökkentik a cirróA béta-receptor-blokád védi a szívet a katekolaminok kardiotoxikus hatásával szemben a mesenteriális erekben kifejtett $a$-adrenerg hatás révén vazokonstrikciót provokál, amely a szplanchnikus vazodilatáció mérséklésén át csökkenti a porta nyomását Sajnos a betegek egy részében adásuk kontraindikált. A betegek egy másik csoportjában aPVG-mérések szerint nem csökkentik a portanyomás (az ún. nonreszponder betegek).

A portális hipertenzió csökkentésének másik módja a TIPSS behelyezése, amely megelözi a WV kin azonban HE-t provokálhat elsősorban azokban a betegekben, akiknek a májbetegségük elörehaladott stádi-

A VV szemponjából nagy rizikójú (nagy, vörös foltokat mutató) varixokat EBL elvégzésével lehet eradikálni. Ez ugyan a vérzést megelózi, de a portában uralkodó nyomást nem befolyásolja.

\section{Primer profilaxis}

Kontraindikáció hiányában az első választandó szer az NSBB, amely a varixok megjelenését és a kis varixok növekedését nem befolyásolja. Emiatt a jelenlegi ajánlás érvelmében a kezelést jelentos vérzéskockázat esetén (nagy varixok, vagy merettol fúggetlenul, ha rajtuk vorōs foltozottság látszik, vagy ha a cirrózis Child-Pugh C stádiumú) melyet 2×10-20 mg-ról assan több nely

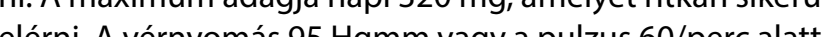
értéke A vérnyomás $95 \mathrm{Hgmm}$ vagy a pulzus $60 /$ perc alatti ascitesük van a maximális ne ascitesúk van, a maximál ś napi adag $160 \mathrm{mg}$. A nonresz-

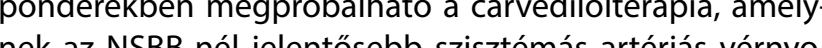
máscsökkentő há́sa van. Ez elsősorban dekomén betegoknen jelenthet probémát Adagja 6,25-12,5 mg-ó $50 \mathrm{mg}$-ig emelotö. $\mathrm{Ha}$ a beteg nem tolerálja zelést vagy kontraindikáció áll fenn nagy varixok esetén zelést, vagy kontraindikáció áll fenn, nagy varixok esetén éte is vénén az NSBB és az EBL hatékonysága mekegyezó az első vérzés megelózésében. A két módszer (NSBB+EBL)

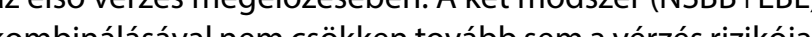

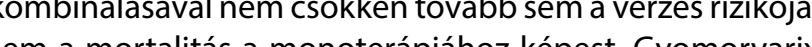
esén primer prevenció céliából egy tanulmány szerin a cianoakriláttal történó injektáĺs hatékonyabb mint az NSBB. Egyelőre erre mé kellő bizonyték nem áll rendel-

\section{Szekunder profilaxis}

Az újravérzés kockázata magas, egy-két éven belül 60 $70 \%$. Megfelelóen alkalmazott profilaxis mellett azonban ez a kockázat jelentősen mérsékelhető. Szekunder prevencióra kombinált kezelés ajánott (NSSB+EBL) mivel jentősebben cö̈kkenti az újravérzés valószínúségét monoterápiaként alkalmazott gyógyszeres vagy az EBLkezeléshez képest. Gyomorvarixokból származó úiravérzés megakadályozására az ismételt cianoakrilát-kezelés tán hatékonyazb, mint az NSBB, és a kombinált terápia ezen az eredményen nem javít.

Gyakran ismétlődő VV vagy NSBB-kontraindikáció esetén varix lokalizációjától függetlenül a TIPSS behelyeź́s kell megfontolni.

A TIPSS hatékonyan csökkenti a porta nyomását az újravérzés kockázatát és a halálozást is. Lehetnek azon ujnemkivánatos hatásai. A legsúlyosabb ezek közül a vér elterelése miatt kialakuló vérellátási zavar a májban, következményes akut májelégtelenséggel, amely 15-18 MELD-pont alatt ritka. Ennél gyakoribb szövődmény a HE kialakulása, rosszabbodása, amely a kezeltek $40 \%$-ában várható, gyakrabban akkor, ha a betegnek korabban volt
HE-je, idős, súlyos máj- és vesefunkciós elégtelenség áll fenn. Ezért nem javasolt a beavatkozás, ha a szérum bilirubinszintje $>51 \mu \mathrm{mol} / \mathrm{l}$, és a vérlemezkeszám $<75000 / \mu \mathrm{l}$, akut ( $\geq 2$. fokozatú) vagy krónikus, manifeszt $\mathrm{HE}$ áll fenn Nem javasolt továbbá zajló infekciós epizód, progressziv vesemüködési zavar, súlyos szisztolés vagy diasztolés szívmüködési zavar és pulmonalis hipertenzió fennállás esetén sem (5). Ugyanakkor akut vérzés kapcsán, életmentő TIPSS esetén abszolút kontraindikáció nincs, az elönyöket és a hátrányokat mérlegelve kell dönten

\section{Irodalom \\ 1. Bosch J, Groszmann RJ, Shah VH. Evolution in the understanding of the

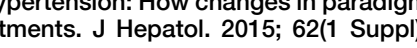

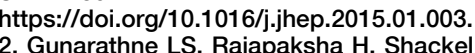 2. Gunarathne LS, Rajapaksha H, Shackel N, et al. Cirhotic portal hyper-
tension: From pathophysiology to novel therapeutics. World $J$ Gastroente- rol. 2020; $26:$ : 6111-6140.
https://doi.org/10.3748/wig.v26.i40.6111. 3. Abraldes $\mathrm{JG}$, iwakiri $Y$, Loureiro-Silva $\mathrm{M}$, et al. Mild increases in porta pressure upregulate vascular endothelial growth factor and end indthelia
nitric oxide synthase in the intestinal microcirculatorory bed, lending to hyperdynamic state. Am J Physiol Gastrointest Liver Physiol. 2006; 290:

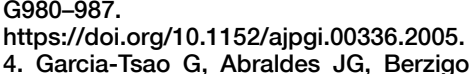 \\ 4. Garcia-Tsao G, Abraldes JG, Berzigotti A, et al. Portal hypertensive
bleeding in cirrhosis: risk stratification, diagnosis, and management: 2016 practice guidance by the American Association for the Study of Liver Dis

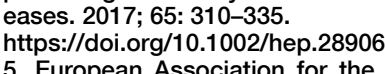 \\ 5. European Association for the Study of the Liver. Electronic address
easloffice@easloffice.eu; European Association for the Study of the Liver

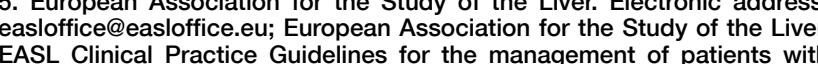 decompensated cirrhosis. J Hepatol. 2018; 69: 406-460. doi: 10.1016/j. hep. 2018.03 .02
$6 . D$ D'Amico G, 6. 'Amico G, Pagliaro L, Bosch J. Pharmacological treatment of portal
ypertension: an evidence-based approach. Semin Liver Dis. 1999; 19 : https://doio.org/10.1055/s-2007-1007133.

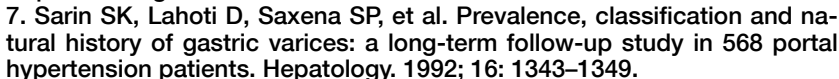

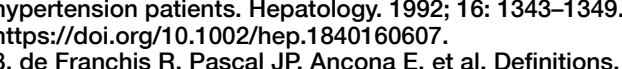 herapeutic strategies in portal hypertension. A Consensus Develogy an Workshop, Baveno, Lake Maggiore, Italy, April 5 and $6,1990$. . $J$ Hepatol.
1992; 15: 256-261. 9. Sarin SK, Kumar A, Angus PW, et al al. Asian Prot Study of the Liver (APASL) Working Party on Portal Hypertension. Diagno- sis and management of acute variceal bleeding: Asian Pacififi Associatition
for Study of the Liver recommendations. Hepatol Int. 2011: $5: 607-62$. hittps://doi.org/10.1007/s12072-010-9236-9.
10. Graham $\mathrm{DY}$, Smith JL. The course of patients after variceal hemorrhage. 10. Graham DY, Smith JL. The courseg.
Gastroenterology. 1981; 80: 800-809.

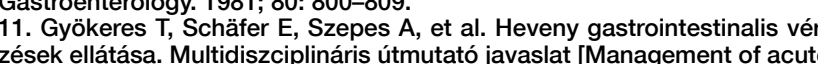

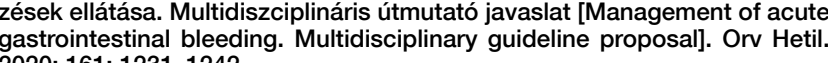 2020; $161: 1231-1242$.
https://doi.org/10.1556/650.2020.31807.}

\section{Összefoglalás}

AVV a májzsugor súlyos akut dekompenzációja, amelynek kialakulása a portában uralkodó nyomástól függ. Magas halálozása miatt a sok beteg adatainak elemzése alapján született irányelvek alkalmazása kötelezö, mivel ez biztositja a lehetó legjobb túlélest. A VV-t mindenképpen jobb megelőzni, mint kezelni. Megelőzése a porta nyomásának csökkentésén és a cirrózis megfeleló vezetésén, gondozásán alapszik.

12. Scott S, Antonaglia V, Guiotto G, et al. Two-hour lactate clearance pre-
dicts negative outcome in patients with cardiorespiratory insufficieiency. Crit

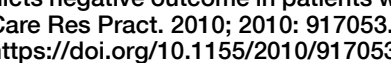

3. Bernard $B$, Grangé $J D$, Khac $E N$, et al. Antibiotic prophylaxis for the

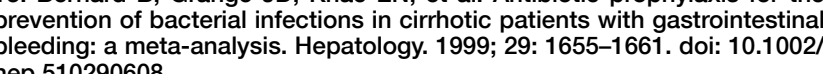
hep. 510290608 .
14. Tandor $P$ P.ldes JG, Keough A, et al. Risk of Bacterial Infection in Patients With Cirrhosis and Acute Variceal Hemorrhage, Based on Child-
Pugh Class, and Effects of Antibiotics. Clin Gastroenterol Hepatol. 2015;
$13: 1189-1196.92$

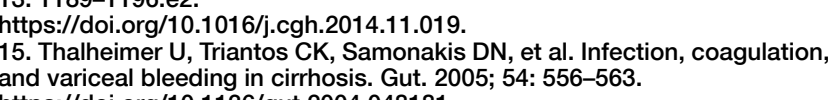

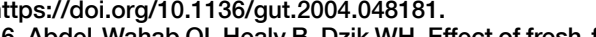

usion on prothrombin time and bleeding in in patitents -rith with mild coagualation abnormalitities. Transfusion. 2006; 46: 1279-1285.

7. Lisman T, Bernal W. Management of Hemostatic Disorders in Patients

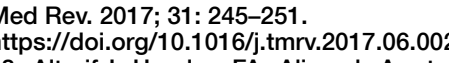
1. Altraif I, Handoo FA, Aljuman A, et al. Effect of erythromycin before
endoscopy in patients presenting with variceal bleeding: a prospective

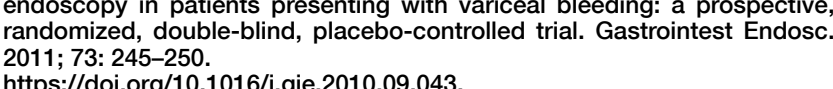

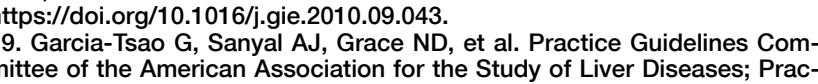
tice Parameters Committee of the American College of Gastroenterology.
trevention and

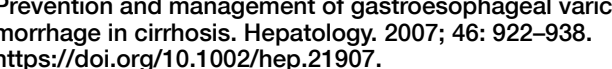

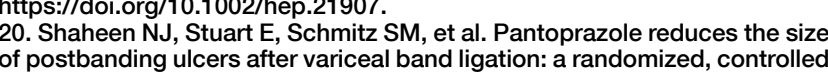

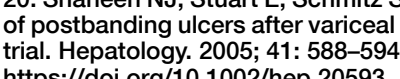

21. Rios Castellanos E, Seron P, Gisbert JP, et al. Endoscopic injection of gastric varices in poepole with portal hypertension. Cochrane Database https://doi.org/10.1002/14651858.CD010180.pub2. 22. Chau TN, Patch D, Chan YW, et al. "Salvage" transjugular intrahepatic

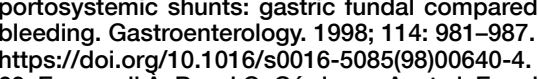

versus esophageal stent inardenas $\mathrm{A}$, et al. Esophonageal balloon tamponade versus esophageal stent in controlling acute refractory variceal bleeding: A
multicenter randominizd, controlled trial. Hepatology. 2016; $63:$ 1957-1967. 